\title{
Effect of the factor inhibiting germinal vesicle breakdown on the disruption of gap junctions and cumulus expansion of pig cumulus-oocyte complexes cultured in vitro
}

\author{
N. Isobe ${ }^{1}$ and T. Terada ${ }^{2 *}$ \\ ${ }^{1}$ Animal Science, Graduate School for International Development and Cooperation, \\ Hiroshima University, Higashi-Hiroshima, 739-8529 Japan; and ${ }^{2}$ Animal Reproduction, \\ Faculty of Applied Biological Science, Hiroshima University, Higashi-Hiroshima, \\ 739-8528 Japan
}

The present study was undertaken to explore the regulatory mechanisms for meiotic resumption of pig cumulusoocyte complexes (COCs) by assessing the nuclear status of oocytes, the degree of gap junction cell-to-cell communication and cumulus expansion after culture of various numbers of COCs in $10 \mu \mathrm{l}$ droplets of medium for $24 \mathrm{~h}$. Gap junction communication was examined by confocal laser scanning microscopy after injection of a fluorescent dye, lucifer yellow, into the oocytes. When one, three or six COCs were cultured in a $10 \mu \mathrm{l}$ droplet, germinal vesicle breakdown was observed in $>70 \%$ of oocytes; increasing the number of COCs in a droplet further actually decreased the proportion of oocytes undergoing germinal vesicle breakdown (10 COCs: $49 \% ; 20$ COCs: $21 \% ; 40$ COCs: $13 \%)$. When six COCs were cultured in a
$10 \mu \mathrm{l}$ droplet of conditioned medium (prepared previously by culturing 20 intact and oocytectomized COCs for $24 \mathrm{~h}$ ), the proportion of oocytes undergoing germinal vesicle breakdown was significantly reduced compared with the proportion in fresh medium. An increase in the proportion of category 1 COCs (all gap junctions within cumulus cells and between cumulus cells and oocyte are functionally maintained) was achieved by increasing the number of COCs cultured in a $\mathbf{1 0} \mu \mathrm{l}$ droplet. The addition of conditioned medium to the fresh medium at a concentration of $\mathbf{5 0} \%$ significantly inhibited cumulus expansion. From these results, it is concluded that the factors secreted by cumulus cells regulate the disruption of gap junctions and cumulus expansion, and concurrently control the incidence of germinal vesicle breakdown in pig COCs.

\section{Introduction}

According to Eppig (1982), maturation of mouse oocytes has already started $3 \mathrm{~h}$ after hCG injection, whereas the gap junctions between oocytes and cumulus cells are not disrupted in the first $6 \mathrm{~h}$ after hCG injection. Culture of mouse cumulus-oocyte complexes (COCs) for $3 \mathrm{~h}$ in the presence of $\mathrm{FSH}$ initiates the resumption of meiotic maturation despite intact metabolic coupling between cumulus cells and oocytes (Salustri and Siracusa, 1983). Larsen et al. $(1986,1987)$ observed a close temporal correlation between the loss of cumulus cell-cumulus cell gap junctions and resumption of meiotic maturation in superovulated rats. Isobe et al. (1998) found that, in pigs, the proportions of oocytes undergoing germinal vesicle breakdown (GVBD) at 16,24 and $32 \mathrm{~h}$ of cultivation were much higher than the proportion in COCs in which all gap junctions within cumulus cells and between cumulus cells and oocytes were disrupted. Furthermore, a significant positive correlation $(r=0.99, P<0.01)$ was observed between the propor-

*Correspondence

Email: tterada@hiroshima-u.ac.jp tion of oocytes undergoing GVBD and the proportion of COCs that had lost gap junctions, at least within all cumulus cell layers other than the innermost layer. From these results, it was concluded that meiotic resumption in pig oocytes is induced by disruption of gap junctions within cumulus cells (Isobe et al., 1998).

Petr et al. (1989) reported that when 40 pig COCs were cultured in a $10 \mu \mathrm{l}$ droplet of medium for $24 \mathrm{~h}$, GVBD in the oocytes was suppressed, and a significantly higher proportion of oocytes undergoing GVBD was observed in denuded oocytes compared with COCs when ten denuded oocytes were cultured with 40 COCs in a $10 \mu \mathrm{l}$ droplet. Increasing the number of bovine COCs to 40 per $10 \mu \mathrm{l}$ medium also resulted in a significant inhibition of meiotic resumption compared with controls containing 10 COCs per $50 \mu \mathrm{l}$ medium (Sirard et al., 1992). From these results, these authors proposed that the factor inhibiting GVBD is generated in the cumulus cells and secreted into culture medium and might cause suppression of GVBD through the mediation of cumulus cells.

On the basis of the study by Isobe et al. (1998) and the reports showing that there is a GVBD inhibitor that is transferred directly from cumulus cells to oocytes via gap junctions (Eppig, 1982; Larsen et al., 1987; Isobe et al., 
1998), it is possible that intact gap junction communication allows direct transfer of the GVBD inhibitor from cumulus cells to oocytes, resulting in inhibition of GVBD. However, the mechanism by which the factor of cumulus cell origin maintains the gap junction communication between cumulus cells surrounding oocytes is still not understood completely.

The aim of the present study was to explore the regulatory mechanism for meiotic resumption of pig COCs further by investigating the relationship between the nuclear status of oocytes and the degree of gap junction cell-to-cell interaction when various numbers of COCs were cultured in $10 \mu \mathrm{l}$ medium for $24 \mathrm{~h}$.

\section{Materials and Methods}

\section{Oocyte collection}

Ovaries were collected from prepubertal gilts at a local abattoir and were transported to the laboratory in $0.85 \%$ $(\mathrm{w} / \mathrm{v}) \mathrm{NaCl}$ with $0.1 \mathrm{mg}$ kanamycin $\mathrm{ml}^{-1}$ (Meiji Seika, Tokyo) at about $35^{\circ} \mathrm{C}$ within $2 \mathrm{~h}$. The surfaces of follicles ranging from 3 to $8 \mathrm{~mm}$ in diameter were cut with a razor and oocytes were collected by scraping the inner surface of the follicle wall using a surgical blade. The oocytes were placed in prewarmed PBS supplemented with 5\% (v/v) bovine serum (Nacalai Tesque, Kyoto). Oocytes with a complete and compact cumulus mass were selected and washed several times in medium (TCM-199 with Earle's salts (Gibco BRL, Grand Island, NY) supplemented with 10 iu hCG $\mathrm{ml}^{-1}$ (Teikokuzouki, Tokyo), $10 \mathrm{iu}$ pregnant mare serum gonadotrophin $\mathrm{ml}^{-1}$ (Teikokuzouki), $1 \mu \mathrm{g}$ oestradiol $\mathrm{ml}^{-1}$ (Sigma Chemical Co, St Louis, MO), $50 \mu \mathrm{g}$ gentamicin sulphate $\mathrm{ml}^{-1}$ (Sigma) and $10 \%(\mathrm{v} / \mathrm{v})$ fetal calf serum (Gibco)).

\section{Effect of numbers of COCs cultured in a $10 \mu$ I droplet on GVBD and the degree of gap junction disruption}

Groups of one, three, six, ten, 20 and 40 COCs were transferred to $10 \mu \mathrm{l}$ droplets of culture medium covered with warm mineral oil (E. R. Squibb and Sons Inc., Princeton, $\mathrm{NJ}$ ) in $35 \mathrm{~mm}$ polystyrene dishes and cultured for $24 \mathrm{~h}$ at $39^{\circ} \mathrm{C}$ in a humidified atmosphere of $5 \% \mathrm{CO}_{2}$ in air.

At the end of cultivation, some COCs were denuded by vortexing for $1.5 \mathrm{~min}$ in PBS supplemented with $5 \%$ bovine serum and the remaining cumulus cells attached to oocytes were removed mechanically by repeated pipetting with a small-bore pipette. The oocytes were fixed for $>48$ $\mathrm{h}$ in acetic acid:ethanol $(1: 3 ; \mathrm{v} / \mathrm{v})$ at room temperature and stained with $1 \%(\mathrm{w} / \mathrm{v})$ lacmoid in $45 \%(\mathrm{v} / \mathrm{v})$ acetic acid for examination by phase-contrast microscopy. The oocytes were classified according to the method of Hunter and Polge (1966) as having an intact germinal vesicle or having undergone GVBD. Nuclear status of germinal vesicle arrested oocytes was further divided into GV I, GV II, GV III or GV IV according to Motlik and Fulka (1976).

The remaining COCs were used for assessment of gap junction status by the injection of fluorescent dye. The dye transfer experiment was conducted as described by Isobe et al. (1998). In brief, oocytes surrounded by cumulus cells were injected with about $4 \mathrm{pl}$ of $10 \%(\mathrm{w} / \mathrm{v})$ lucifer yellow $\mathrm{CH}$ (Sigma) on a heated stage $\left(37^{\circ} \mathrm{C}\right)$ of an inverted microscope at $\times 100$ magnification using a Hoffman Modulation contrast system (Modulation Optics Inc, Greenvale, NY). The spread of the dye from the oocyte into surrounding cumulus cells was monitored using confocal laser scanning microscopy (ACAS 570; Meridian Instruments Inc, Okemos, MI) with a $\times 100$ oil objective within 10-15 min after injection.

The COCs were classified into four categories according to the degree of dye transferred into the cumulus cells: category 1: the dye was transferred to all layers of cumulus cells surrounding the oocyte (Fig. 1a,b); category 2: the dye was transferred to more than two inner layers of $\mathrm{cu}-$ mulus cells but not to all layers of the cumulus cells (Fig. 1c,d); category 3: the dye was transferred to the innermost layer of cumulus cells only (Fig. 1e,f); and category 4: the dye was not transferred to cumulus cells (Fig. 1g,h).

\section{Effect of the factor secreted by cumulus cells on expansion of cumulus cells}

After 20 COCs were cultured in each $10 \mu \mathrm{l}$ droplet of medium for $24 \mathrm{~h}$, the medium was collected in an Eppendorf tube and stored frozen at $-30^{\circ} \mathrm{C}$ as conditioned medium until used. Six COCs were cultured in $10 \mu \mathrm{l}$ droplets of $0 \%$ (fresh medium), 50\% (5 $\mu \mathrm{l}$ fresh medium and $5 \mu \mathrm{l}$ conditioned medium) or $100 \%$ conditioned medium for $24 \mathrm{~h}$. At the end of cultivation, the cumulus cell expansion was scored on the subjective scales of \pm (no observable expansion; Fig. 2a), + (enlargement of cumulus mass but no cumulus cells separated; Fig. 2b) and ++ (some cumulus cells separated; Fig. 2c). Cumulus cells of ++ expansion were a little sticky.

\section{Effect of conditioned medium prepared with oocytectomized COCs on GVBD of oocytes}

Oocytectomy was conducted as described by Buccione et al. (1990). Each COC was held with the holding pipette using negative pressure. A lancing pipette, fashioned in the manner of a standard microinjection pipette, was pushed

Fig. 1. Light micrographs ( $a, c$, e and g) and confocal laser scanning microscopic images (b, $d, f$ and h) of various categories of lucifer yellow transfer in pig cumulus-oocyte complexes. (a,b) Category 1: dye transferred to all layers of cumulus cells surrounding oocytes. $(c, d)$ Category 2: dye transferred to more than two inner layers of cumulus cells but not all layers of the cumulus cells. (e,f) Category 3 : dye transferred to only the innermost layer of cumulus cells. (g,h) Category 4: dye not transferred to cumulus cells. Scale bars represent $50 \mu \mathrm{m}$. 

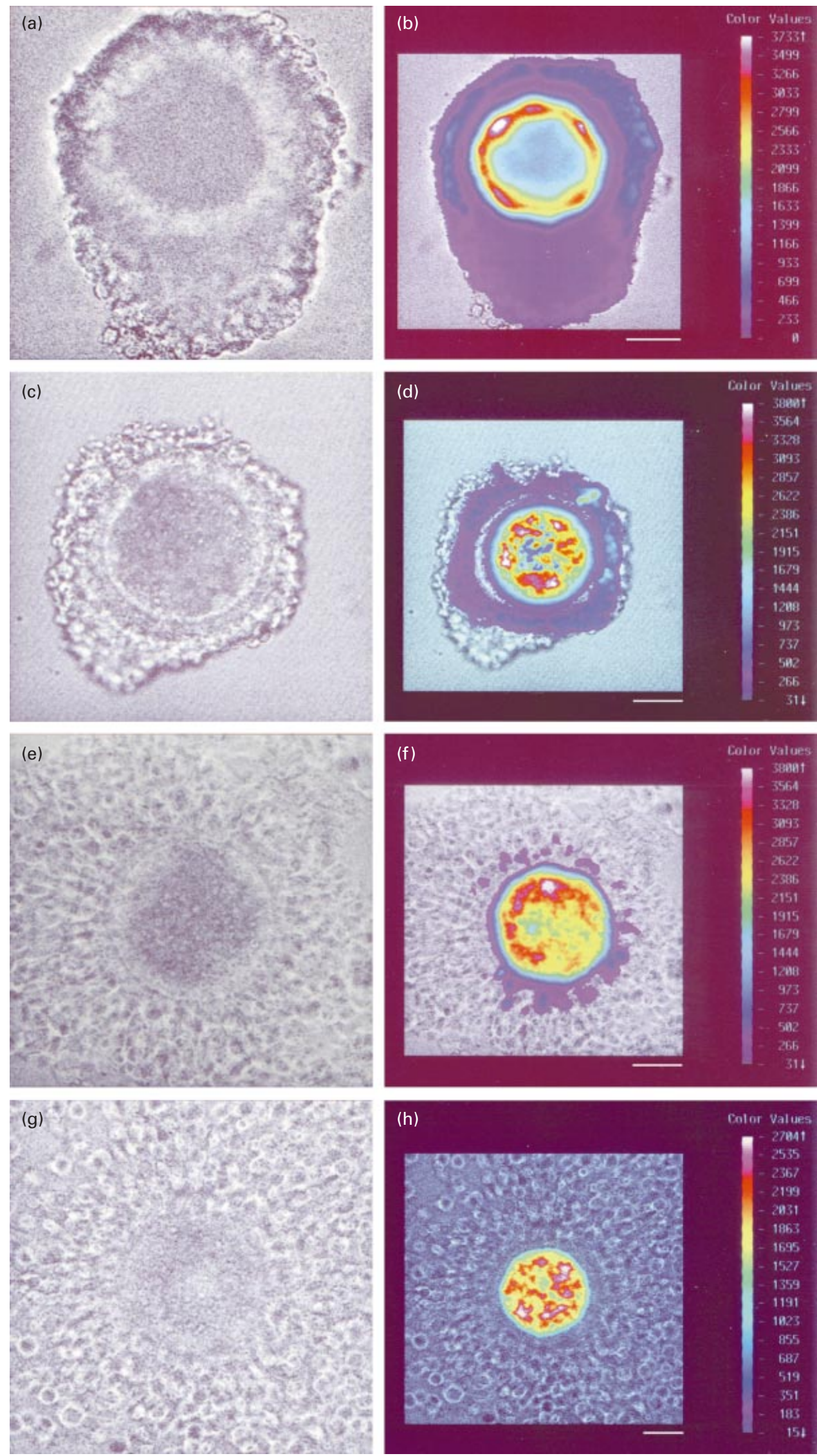

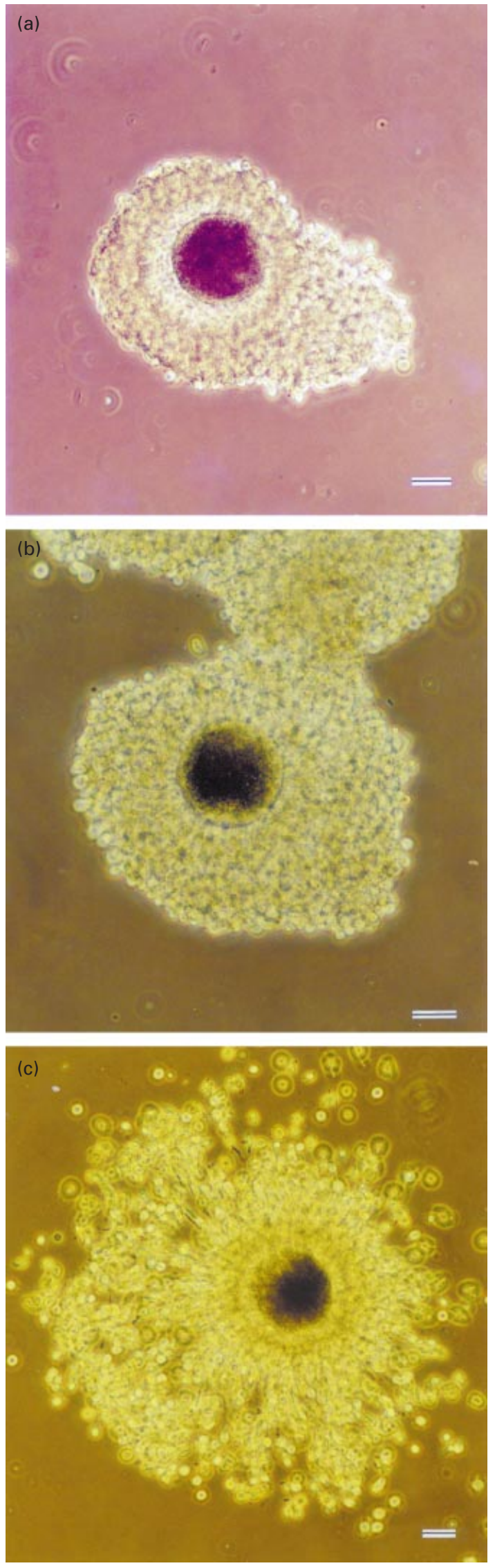

through the layers of cumulus cells and completely through the oocyte and into the holding pipette. After withdrawal of the lancing pipette, negative pressure in the holding pipette aspirated most or all of the oocyte. The complexes deprived of the ooplasm will hereafter be called oocytectomized COCs. Twenty oocytectomized COCs were cultured in a $10 \mu \mathrm{l}$ droplet of medium for $24 \mathrm{~h}$ and the medium was defined as the oocytectomized COCconditioned medium. Control conditioned medium was prepared concomitantly using fresh, intact COCs as described earlier. After $24 \mathrm{~h}$ cultivation of six COCs in $10 \mu \mathrm{l}$ droplets of both control conditioned and oocytectomized COC-conditioned medium, the oocytes were fixed, stained and their nuclear status was assessed as described above.

\section{Reversibility of meiotic inhibition in COCs cultured in a $10 \mu$ l droplet of medium}

After primary incubation of 20 COCs for $24 \mathrm{~h}$ in a $10 \mu \mathrm{l}$ droplet of fresh medium, COCs were washed several times in medium and cultured for a further $24 \mathrm{~h}$ in a $100 \mu \mathrm{l}$ droplet of fresh medium. The COCs were denuded, fixed and stained as above. As a control, 20 COCs were cultured in a $100 \mu \mathrm{l}$ droplet of fresh medium for 24 and $48 \mathrm{~h}$ and the nuclear status of each COC was also examined.

\section{Statistical analysis}

Each experiment was replicated at least three times. The data from each experiment were pooled for presentation and a chi-squared analysis was used to test significance among groups. The percentage data were subjected to arc sine transformation before correlation analyses were carried out using Student's $t$ test. The level of significance was $P<0.05$.

\section{Results}

Petr et al. (1989) reported that the incidence of GVBD decreases with increasing numbers of COCs cultured in a $10 \mu \mathrm{l}$ droplet. In the present study, various numbers of COCs were cultured in $10 \mu \mathrm{l}$ droplets for $24 \mathrm{~h}$ to determine whether this quantitative inhibitory influence of cumulus cells on GVBD of oocytes is also observed under our culture conditions. The proportions of oocytes undergoing GVBD after cultivation are shown (Table 1). Culture of a small number ( $n=1,3$ and 6) of COCs in each $10 \mu \mathrm{l}$ droplet resulted in higher GVBD (72-81\%). However, when ten COCs were cultured in a $10 \mu \mathrm{l}$ droplet, the proportion of oocytes with GVBD decreased significantly. Moreover, cultivation of $>20$ COCs in a $10 \mu$ droplet produced a more marked decrease in the proportion of GVBD

Fig. 2. Light micrographs of various degrees of cumulus expansion in pig cumulus-oocyte complexes. (a) \pm Degree: no expansion was observed. (b) + Degree: cumulus mass was enlarged but no cumulus cells were separated. (c) ++ Degree: some cumulus cells were separated. Scale bars represent $50 \mu \mathrm{m}$. 
Table 1. Effect of the number of pig cumulus-oocyte complexes (COCs) cultured in a $10 \mu \mathrm{l}$ droplet of medium on germinal vesicle breakdown of oocytes

\begin{tabular}{|c|c|c|c|c|}
\hline \multirow{2}{*}{$\begin{array}{l}\text { Number of COCs } \\
\text { in } 10 \mu \mathrm{l} \text { medium }\end{array}$} & \multirow{2}{*}{$\begin{array}{c}\text { Number of } \\
\text { oocytes examined }\end{array}$} & \multicolumn{2}{|c|}{ Number $(\%)^{*}$ of oocytes with } & \multirow{2}{*}{$\begin{array}{c}\text { Number }(\%)^{* *} \text { of } \\
\text { degenerated oocytes }\end{array}$} \\
\hline & & Germinal vesicles & GVBD & \\
\hline 1 & 74 & $16(23.9)^{a}$ & $51(76.1)^{\mathrm{a}}$ & $7(9.5)^{\mathrm{ab}}$ \\
\hline 3 & 77 & $14(18.7)^{a}$ & $61(81.3)^{\mathrm{a}}$ & $2(2.6)^{\mathrm{a}}$ \\
\hline 6 & 58 & $14(27.5)^{\mathrm{a}}$ & $37(72.5)^{\mathrm{a}}$ & $7(12.1)^{b}$ \\
\hline 10 & 113 & $53(51.0)^{b}$ & $51(49.0)^{b}$ & $9(8.0)^{\mathrm{ab}}$ \\
\hline 20 & 71 & $50(79.4)^{\mathrm{c}}$ & $13(20.6)^{c}$ & $8(11.3)^{b}$ \\
\hline 40 & 138 & $109(87.2)^{c}$ & $16(12.8)^{c}$ & $13(9.4)^{a b}$ \\
\hline
\end{tabular}

GVBD: germinal vesicle breakdown.

*Percentage of the number of oocytes examined except for degenerated oocytes.

**Percentage of the number of oocytes examined.

abc Values within a column with different superscripts are significantly different $(P<0.05)$.

Table 2. Effect of the number of pig cumulus-oocyte complexes (COCs) cultured in a $10 \mu$ droplet of medium on the degree of dye transfer

\begin{tabular}{|c|c|c|c|c|c|}
\hline \multirow{2}{*}{$\begin{array}{l}\text { Number of } \\
\text { COCs cultured } \\
\text { in } 10 \mu \mathrm{l} \text { droplet }\end{array}$} & \multirow{2}{*}{$\begin{array}{c}\text { Number of } \\
\text { COCs examined }\end{array}$} & \multicolumn{4}{|c|}{ Number $(\%)$ of COCs in each category } \\
\hline & & 1 & 2 & 3 & 4 \\
\hline 1 & 30 & $0(0.0)^{a}$ & $23(76.7)^{\mathrm{a}}$ & $4(13.3)^{a}$ & $3(10.0)^{a b}$ \\
\hline 3 & 49 & $1(2.0)^{\mathrm{a}}$ & $35(71.4)^{\mathrm{a}}$ & $7(14.3)^{\mathrm{a}}$ & $6(12.2)^{\mathrm{ab}}$ \\
\hline 6 & 49 & $5(10.2)^{a b}$ & $29(59.2)^{\mathrm{a}}$ & $8(16.3)^{\mathrm{a}}$ & $7(14.3)^{\mathrm{ac}}$ \\
\hline 10 & 58 & $12(20.7)^{\mathrm{b}}$ & $33(56.9)^{\mathrm{a}}$ & $3(5.2)^{\mathrm{ab}}$ & $10(17.2)^{\mathrm{a}}$ \\
\hline 20 & 43 & $31(72.1)^{\mathrm{c}}$ & $11(25.6)^{b}$ & $0(0.0)^{b}$ & $1(2.3)^{b}$ \\
\hline 40 & 65 & $60(92.3)^{d}$ & $2(3.1)^{\mathrm{c}}$ & $0(0.0)^{b}$ & $3(4.6)^{b c}$ \\
\hline
\end{tabular}

Category 1: dye transferred to all layers of cumulus cells surrounding oocyte; category 2: dye transferred to more than two inner layers of cumulus cells but not all layers of the cumulus cells; category 3: dye transferred to the innermost layer of cumulus cells only; and category 4: dye not transferred to cumulus cells.

abcdValues within a column with different superscripts are significantly different $(P<0.05)$.

oocytes and all the differences in these proportions between the 20 or 40 COCs groups and the $<10$ COCs groups were significant. With regard to the proportion of degenerated oocytes, there were significant differences between some groups, but a proportional increase together with an increase in the number of COCs in a $10 \mu$ l droplet was not detected.

After cultivation of various numbers of COCs in a $10 \mu \mathrm{l}$ droplet for $24 \mathrm{~h}, \mathrm{COCs}$ were injected with lucifer yellow and the degree of dye transfer from the oocyte into cumulus cells was observed (Table 2). When one, three or six COCs were cultured in a $10 \mu \mathrm{l}$ droplet, more than half of the COCs were in category 2, whereas only a few COCs underwent a category 1 degree of dye transfer. When ten COCs were cultured in $10 \mu$ l droplets, a significantly higher proportion of COCs remained in category $1 \mathrm{com}$ pared with the group of one or three COCs in a $10 \mu \mathrm{l}$ droplet. Further increasing the number of COCs cultured in a $10 \mu \mathrm{l}$ droplet led to a marked increase in the proportion of COCs in category 1 , reaching a maximum value in the group of 40 COCs cultured in a $10 \mu \mathrm{l}$ droplet (92\%).

The proportion of GVBD oocytes and each percentage of the total number of category 2, 3 and 4 COCs, the total number of category 3 and 4 COCs, and the total number of category 4 COCs, were calculated for each group to examine the relationship between induction of GVBD and the degree of disruption of cumulus-cumulus cell or oocyte-cumulus cell gap junctions (Fig. 3). The category 2, 3 and 4 COCs represent the COCs in which gap junctions within at least the outermost cumulus cell layers were disrupted. Category 3 and 4 COCs represent the COCs in which the gap junctions from within the outer cumulus layers to at least two inner layers of cumulus cells were disrupted. Category 4 COCs represent the COCs in which the gap junctions between the oocyte and the cumulus cells were disrupted. The percentages of category 3 and 4 COCs and the percentages of category 4 COCs were much lower than the proportion of oocytes undergoing GVBD in any of the groups. In contrast, the percentage of total COCs with category 2, 3 or 4 disruption was slightly higher than the proportion of GVBD oocytes in all groups, except for the group of 40 COCs in a $10 \mu \mathrm{l}$ droplet. A significant positive correlation was established between the percentage of total COCs with category 2, 3 or 4 disruption and the proportion of GVBD oocytes $(r=0.98, P<0.01)$. 


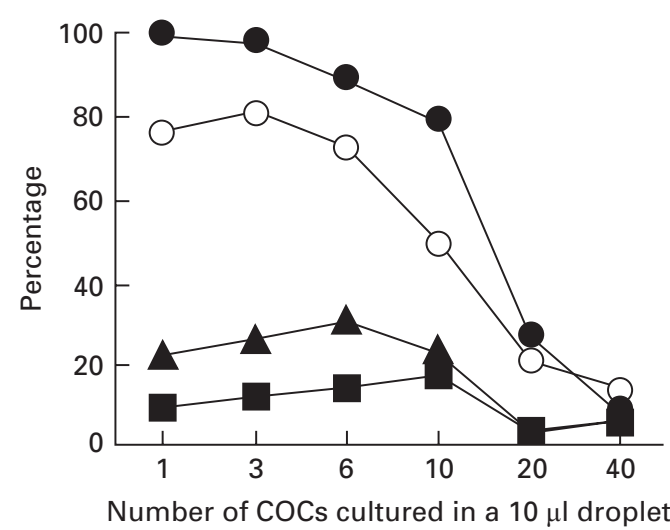

Fig. 3. Relationship between germinal vesicle breakdown (GVBD) and the degree of dye transfer in pig cumulus-oocyte complexes (COCs). $\bigcirc$ : Percentage of GVBD oocytes. Percentage of the total number of COCs with category 2, 3 and 4 degrees of dye transfer. $\boldsymbol{\Delta}$ : Percentage of the total number of COCs with category 3 and 4 degrees of dye transfer. Percentage of the total number of COCs with category 4 degrees of dye transfer.

The degree of cumulus cell expansion of COCs that were cultured in a $10 \mu \mathrm{l}$ droplet of different medium containing various volumes of the medium conditioned by culturing 20 intact COCs in the same volume droplet is shown (Table 3). Culture of six COCs in a $10 \mu \mathrm{l}$ droplet of fresh medium (with no conditioned medium) resulted in expansion of outer cumulus cells in most COCs. However, an increase in the concentration of conditioned medium significantly reduced the percentage of COCs with a ++ degree of cumulus cell expansion. Expansion of cumulus cells in nearly all COCs (99\%) was inhibited completely by cultivation in $100 \%$ conditioned medium, and highly significant differences in the percentage of COCs with ++ expansion were observed between the COCs cultivated in $100 \%$ conditioned medium and other groups.

The proportion of oocytes undergoing GVBD when six COCs were cultured for $24 \mathrm{~h}$ in medium conditioned by 20 oocytectomized COCs is shown (Table 4). Culture of COCs in the oocytectomized COC-conditioned medium resulted in a similar level of GVBD as did culture in the medium conditioned by 20 intact COCs. The proportions of oocytes with GVBD in both the oocytectomized COCand intact COC-conditioned medium groups were significantly lower than the proportion in the fresh medium group. When six denuded oocytes were cultured in a $10 \mu \mathrm{l}$ droplet of COC-conditioned medium, $66.7 \%$ of oocytes underwent GVBD (data not shown).

When 20 and 40 COCs were cultured in $10 \mu$ droplets of medium, nuclear status of germinal vesicle-arrested oocytes was divided further into GV I, GV II, GV III or GV IV (Table 5). More than $70 \%$ of oocytes in both groups were kept at the GV I stage. Progression to GV II and GV IV stages was also observed in 6 and $24 \%$ of germinal vesicle-arrested oocytes in the 20 COC group, and 3 and $14 \%$ of germinal vesicle-arrested oocytes in the 40 COC group.

After culture of 20 COCs in a $10 \mu \mathrm{l}$ droplet of medium for $24 \mathrm{~h}$, the COCs were transferred to a $100 \mu \mathrm{l}$ droplet and cultured for a further $24 \mathrm{~h}$. Culture of 20 COCs in a $100 \mu \mathrm{l}$ droplet for $24 \mathrm{~h}$ led to meiotic progression from prometaphase I to telophase I in $61 \%$ of oocytes, and $31 \%$ of oocytes remained at the germinal vesicle stage (Table 6). About $48 \mathrm{~h}$ was required for oocytes cultured in a $100 \mu \mathrm{l}$ droplet to reach metaphase II (74\% of COCs at metaphase II). When 20 COCs were pre-cultured in a $10 \mu \mathrm{l}$ droplet for $24 \mathrm{~h}$, transfer of COCs to a $100 \mu \mathrm{l}$ droplet resulted in resumption of meiotic maturation in oocytes. More than half of these oocytes reached metaphase II stage within $24 \mathrm{~h}$ after transfer of COCs from the $10 \mu \mathrm{l}$ droplet to the $100 \mu \mathrm{l}$ droplet.

\section{Discussion}

Petr et al. (1989) observed a marked decrease in the proportion of GVBD oocytes as the number of COCs cultured in a $10 \mu \mathrm{l}$ droplet increased, and they postulated that pig cumulus cells produce a factor (or factors) that inhibits GVBD and which is secreted into the surrounding medium. A similar finding was also detected in bovine COCs by Sirard et al. (1992). However, the mechanism of action of the GVBD inhibitor has not been explored at all. The present study was undertaken to elucidate the regulatory mechanism by which this factor (or factors) inhibits GVBD.

In the experiment for confirming the secretion of GVBD-inhibiting factors from COCs into medium, GVBD occurred in $>70 \%$ of oocytes when one, three or six COCs were cultured in a $10 \mu \mathrm{l}$ droplet. In contrast, a large decrease in the proportion of GVBD oocytes was detected when large numbers of COCs were cultured in the same volume of medium (ten COCs: $49.0 \%$; 20 COCs: $20.6 \%$; 40 COCs: $12.8 \%)$. Furthermore, culture of six COCs in a $10 \mu \mathrm{l}$ droplet of conditioned medium also suppressed GVBD of oocytes. Hence, these results indicate strongly that COCs produce a GVBD-inhibiting factor and secrete it into the medium, but it is not possible to determine whether this factor is secreted from the cumulus cells or from the oocyte itself. Therefore, oocytectomized COCs were used to prepare a conditioned medium and six COCs were cultured in the oocytectomized COC-conditioned medium for $24 \mathrm{~h}$. The conditioned medium led to inhibition of GVBD at the same level as was observed in the medium conditioned by intact COCs, indicating that the GVBD-inhibiting factor (or factors) is secreted by cumulus cells per se. The secretion of a granulosa cell- or theca cell-derived factor that inhibits GVBD of oocytes into medium has also been reported in cattle (Richard and Sirard, 1996a,b; Sirard and Bilodeau, 1990).

Culture of many COCs in a small amount of medium raises the possibility that nutrients for oocyte GVBD may 
Table 3. Effect of conditioned medium on cumulus expansion in pig cumulus-oocyte complexes (COCs)

\begin{tabular}{|c|c|c|c|c|c|}
\hline \multirow{2}{*}{$\begin{array}{l}\text { Concentration of } \\
\text { conditioned medium }\end{array}$} & \multirow{2}{*}{$\begin{array}{c}\text { Number of } \\
\text { COCs examined }\end{array}$} & \multirow{2}{*}{$\begin{array}{l}\text { Percentage of } \\
\text { GVBD oocytes }\end{array}$} & \multicolumn{3}{|c|}{ Number $(\%)$ of COCs at each degree of cumulus expansion } \\
\hline & & & \pm & + & ++ \\
\hline 0 & 104 & $72.5^{\mathrm{a}}$ & $3(2.9)^{\mathrm{a}}$ & $8(7.7)^{\mathrm{a}}$ & $93(89.4)^{\mathrm{a}}$ \\
\hline 50 & 91 & nd & $1(1.1)^{\mathrm{a}}$ & $41(45.1)^{b}$ & $49(53.8)^{b}$ \\
\hline 100 & 102 & $32.8^{b}$ & $101(99.0)^{b}$ & $0(0.0)^{c}$ & $1(1.0)^{\mathrm{c}}$ \\
\hline
\end{tabular}

GVBD: germinal vesicle breakdown. nd: not determined.

Cumulus cell expansion was scored on the subjective scales of \pm (no observable expansion), + (enlargement of cumulus mass but no cumulus cells separated) and ++ (some cumulus cells separated).

abc Values within a column with different superscripts are significantly different $(P<0.05)$.

Table 4. Effect of culture in oocytectomized cumulus-oocyte complex-conditioned medium on germinal vesicle breakdown of pig oocytes

\begin{tabular}{|c|c|c|c|c|}
\hline \multirow[b]{2}{*}{ Medium } & \multirow{2}{*}{$\begin{array}{c}\text { Number of } \\
\text { oocytes examined }\end{array}$} & \multicolumn{2}{|c|}{ Number $(\%) *$ of oocytes with } & \multirow{2}{*}{$\begin{array}{c}\text { Number }(\%)^{* *} \text { of } \\
\text { degenerated oocytes }\end{array}$} \\
\hline & & Germinal vesicles & GVBD & \\
\hline OOX conditioned & 71 & $63(92.6)^{a}$ & $5(7.4)^{a}$ & $3(4.2)$ \\
\hline Intact COC conditioned & 113 & $95(88.0)^{\mathrm{a}}$ & $13(12.0)^{\mathrm{a}}$ & $5(4.4)$ \\
\hline Fresh & 105 & $30(30.6)^{b}$ & $68(69.4)^{b}$ & $7(6.7)$ \\
\hline
\end{tabular}

COC: Cumulus-oocyte complex. OOX: oocytectomized cumulus-oocyte complex. GVBD: germinal vesicle breakdown.

*Percentage of the number of oocytes examined except for degenerated oocytes.

**Percentage of the number of oocytes examined.

abValues within a column with different superscripts are significantly different $(P<0.05)$.

Table 5. Nuclear status in germinal vesicle stage of pig cumulus-oocyte complexes (COCs) cultured in $10 \mu \mathrm{l}$ droplets of medium for $24 \mathrm{~h}$

\begin{tabular}{|c|c|c|c|c|c|}
\hline \multirow{2}{*}{$\begin{array}{l}\text { Number of COCs per } \\
10 \mu \mathrm{l} \text { medium }\end{array}$} & \multirow{2}{*}{$\begin{array}{l}\text { Total number of } \\
\text { oocytes with intact } \\
\text { germinal vesicles }\end{array}$} & \multicolumn{4}{|c|}{ Number $(\%)^{*}$ of oocytes at each stage } \\
\hline & & GVI & GV II & GV III & GV IV \\
\hline 20 & 50 & $35(70.0)$ & $3(6.0)$ & 0 & $12(24.0)$ \\
\hline 40 & 109 & $91(83.5)$ & $3(2.8)$ & 0 & 15 (13.8) \\
\hline
\end{tabular}

*Percentage of the total number of oocytes with intact germinal vesicles.

Table 6. Reversibility of germinal vesicle-arrested pig cumulus-oocyte complexes (COCs) cultured in $10 \mu \mathrm{l}$ droplets of medium for $24 \mathrm{~h}$

\begin{tabular}{|c|c|c|c|c|c|c|}
\hline \multicolumn{2}{|c|}{$\begin{array}{l}\text { Volume }(\mu \mathrm{l}) \text { of medium } \\
\text { for culture of } 20 \text { COCs }\end{array}$} & \multirow{2}{*}{$\begin{array}{l}\text { Number } \\
\text { of oocytes } \\
\text { examined }\end{array}$} & \multicolumn{3}{|c|}{ Number (\%) of oocytes at each stage } & \multirow{2}{*}{$\begin{array}{c}\text { Number of } \\
\text { degenerated } \\
\text { oocytes }\end{array}$} \\
\hline First $24 \mathrm{~h}$ & Second $24 \mathrm{~h}$ & & Germinal vesicle & ProM I-T I & Metaphase II & \\
\hline $100^{*}$ & - & 100 & $31(31.0)^{\mathrm{a}}$ & $61(61.0)^{\mathrm{a}}$ & $4(4.0)^{\mathrm{a}}$ & $4(4.0)^{\mathrm{a}}$ \\
\hline $10^{* *}$ & 100 & 98 & $5(5.1)^{b}$ & $27(27.6)^{b}$ & $55(56.1)^{b}$ & $11(11.2)^{\mathrm{b}}$ \\
\hline $100^{* * *}$ & 100 & 61 & $5(8.2)^{b}$ & $8(13.1)^{\mathrm{c}}$ & $45(73.8)^{\mathrm{c}}$ & $3(4.9)^{\mathrm{a}}$ \\
\hline
\end{tabular}

ProM I-T I: Prometaphase I, metaphase I, anaphase I and telophase I.

*Twenty COCs cultured in a $100 \mu \mathrm{l}$ droplet of medium for only $24 \mathrm{~h}$.

**Twenty COCs cultured in a $10 \mu \mathrm{l}$ droplet of medium for $24 \mathrm{~h}$ and then cultured in a $100 \mu \mathrm{l}$ droplet for another $24 \mathrm{~h}$.

***Twenty COCs cultured in a $100 \mu$ d droplet of fresh medium for $48 \mathrm{~h}$.

${ }^{a b c}$ Values within a column with different superscripts are significantly different $(P<0.05)$. 
be depleted from the medium. For example, in mouse COCs, decreasing concentrations of glucose in medium enhance GVBD of oocytes in which GVBD was inhibited by hypoxanthine (Downs and Mastropolo, 1994). If the conditioned medium was short of glucose in the present study, the medium could have promoted GVBD of oocytes. Downs and Mastropolo (1994) reported that when denuded oocytes were cultured in medium containing various concentrations of glucose, glucose had no promoting effect on GVBD of oocytes; however, GVBD of denuded oocytes cultured in a $10 \mu \mathrm{l}$ droplet of conditioned medium was not inhibited. Therefore, in the present study, glucose is probably not limiting in the medium.

When ten and 20 COCs were cultured in a $10 \mu \mathrm{l}$ droplet in the present study, the proportions of oocytes undergoing GVBD were much lower than those observed in the study by Petr et al. (1989). This difference is probably attributable to the different composition of the culture media in each study. In the present study, hormones (hCG, PMSG and oestradiol) were added to the culture media, which was not the case in the study of Petr et al. (1989). Alternatively, the difference in the proportions of GVBD oocytes between the present study and that of Petr et al. (1989) could be due to the number of cumulus cells surrounding the oocyte used. Only oocytes attached to at least three layers of cumulus cells were used in the present study, whereas Petr et al. (1989) did not describe how many layers of cumulus cells surrounded the oocytes.

The decrease in the proportion of oocytes undergoing GVBD that resulted from increasing the number of COCs cultured in a $10 \mu \mathrm{l}$ droplet indicates that a larger quantity of the GVBD-inhibiting factor(s) was accumulated in the culture medium containing higher numbers of COCs. Concomitant with this reduction in the proportion of GVBD oocytes, an increase in the proportion of category 1 COCs (dye transferred to all layers of cumulus cells surrounding the oocyte) was observed as the number of COCs cultured in a $10 \mu \mathrm{l}$ droplet increased. As category 1 COCs were defined as oocytes with entirely functional gap junctions between cumulus cells or cumulus cells and oocytes, it is possible that, in pigs, the GVBD-inhibiting factor(s) inhibits the disruption of gap junctions, thus preventing oocytes from undergoing GVBD by continuous transfer of the inhibitor that was produced by cumulus cells and transported directly to the oocyte (Isobe et al., 1998). However, there is no evidence that the factors that inhibit GVBD and inhibit disruption of gap junctions are the same.

The degree of cumulus cell expansion after culture of six COCs in a $10 \mu \mathrm{l}$ droplet of conditioned medium was assessed to examine the effect of the GVBD-inhibiting factor(s) on expansion of cumulus cells. As the concentration of conditioned medium increased, there was a concomitant significant decrease in the proportion of COCs with ++ expansion and no sign of cumulus cell expansion was detected in $99 \%$ of COCs cultured in 100\% conditioned medium. Furthermore, the conditioned medium produced a significant reduction in the proportion of oocytes undergoing GVBD. These findings indicate that the GVBD-inhibiting factor(s) is present in the conditioned medium and that the expansion of cumulus cells in pig COCs is also regulated by factor(s) secreted by cumulus cells. These observations raise the possibility that the blocking of cumulus cell expansion by GVBD-inhibiting factor(s) is accompanied by functional maintenance of gap junctions between cells, thus preventing oocytes from undergoing GVBD. This interpretation regarding GVBD prevention due to the factor is also supported by the fact that an unknown factor inhibits GVBD of oocytes via cumulus cells (Petr et al., 1989; Richard and Sirard, 1996b).

In the present study, the proportion of category 4 COCs (dye not transferred to cumulus cells) was much lower than the proportion of oocytes undergoing GVBD in each COC group (1-40 per $10 \mu \mathrm{l}$ droplet), indicating that GVBD of oocytes occurred before disruption of cumulus-oocyte gap junctions. In contrast, Dekel and Beer (1980) and Dekel et al. (1981) reported that the interruption of cumulus-oocyte gap junctions could lead to relief of meiotic arrest. The results of the present study also indicate that the proportions of total COCs with category 2, 3 or 4 disruption (which were considered as the disruption of gap junctions within at least the outermost cumulus cells) were considerably higher than the proportion of GVBD oocytes in all groups, except for a group of 40 COCs cultured in a $10 \mu \mathrm{l}$ droplet, and that the positive correlation between these proportions was highly significant. These results indicate strongly that loss of gap junction within cumulus cells triggers the resumption of meiosis in pig oocytes. Similar conclusions regarding the induction of meiotic resumption in mammalian oocytes were derived from studies of rat COCs in vivo (Larsen et al., 1986, 1987) and in vitro (Wert and Larsen, 1989), mouse COCs in vivo (Eppig, 1982) and pig COCs in vivo (Motlik et al., 1986) and in vitro (Isobe et al., 1998).

When 20 and 40 COCs were cultured in a $10 \mu$ droplet for $24 \mathrm{~h}, \mathrm{GV}$ I oocytes were dominant. This finding demonstrates that such culture conditions can block meiosis of oocytes completely. Furthermore, when 20 COCs were cultured in a $100 \mu \mathrm{l}$ droplet after cultivation in a $10 \mu \mathrm{l}$ droplet for $24 \mathrm{~h}$, oocytes completed meiosis in another $24 \mathrm{~h}$ only. This finding indicates that, after cultivation in a $10 \mu \mathrm{l}$ droplet for $24 \mathrm{~h}$, GV I-arrested oocytes are alive and can reach metaphase II faster than oocytes freshly isolated from follicles. It remains to be determined whether COCs cultured in a $10 \mu \mathrm{l}$ droplet for $24 \mathrm{~h}$ and followed by a $100 \mu \mathrm{l}$ droplet for $24 \mathrm{~h}$ can be fertilized normally and develop better than those cultured in a $100 \mu \mathrm{l}$ droplet for $48 \mathrm{~h}$. This contention is supported by Funahashi et al. (1997), who found that exposure of COCs to dibutyryl CAMP for the first $20 \mathrm{~h}$ of culture followed by culture in the absence of the drug for $28 \mathrm{~h}$ for maturation, improves the efficiency of production of pig embryos in vitro. Lonergan et al. (1997) reported that a premature treatment may be necessary to allow the oocytes from 
small follicles in which the final phase of folliculogenesis has been shortened artificially by removal from the follicle, to 'catch up' with those from larger follicles or those matured totally in vivo, which also supports the contention.

The authors thank the staff of the Meat Inspection Office of Onomichi and Hiroshima cities for supplying us with the pig ovaries.

\section{References}

Buccione R, Vanderhyden BC, Caron PJ and Eppig JJ (1990) FSH-induced expansion of the mouse cumulus oophorus in vitro is dependent upon a specific factor(s) secreted by the oocyte Developmental Biology 138 $16-25$

Dekel N and Beers WH (1980) Development of rat oocytes in vitro: inhibition and induction of maturation in the presence or absence of cumulus-oophorus Developmental Biology 75 247-254

Dekel N, Lawrence TS, Gilula NB and Beers WH (1981) Modulation of cell-to-cell communication in the cumulus-oocyte complex and the regulation of oocyte maturation by LH Developmental Biology $\mathbf{8 6}$ 356-392

Downs SM and Mastropolo AM (1994) The participation of energy substrates in the control of meiotic maturation in murine oocytes Developmental Biology 162 154-168

Eppig JJ (1982) The relationship between cumulus-oocyte coupling, oocyte meiotic maturation, and cumulus expansion Developmental Biology $89268-272$

Funahashi H, Cantley TC and Day BN (1997) Synchronization of meiosis in porcine oocytes by exposure to dibutyryl cyclic adenosine monophosphate improves developmental competence following in vitro fertilization Biology of Reproduction 57 49-53

Hunter RHF and Polge C (1966) Maturation of follicular oocytes in the pig after injection of human chorionic gonadotropin Journal of Reproduction and Fertility 12 525-531

Isobe N, Maeda T and Terada T (1998) Involvement of meiotic resumption in the disruption of gap junctions between cumulus cells attached to pig oocytes Journal of Reproduction and Fertility 113 167-172
Larsen WJ, Wert SE and Brunner GD (1986) A dramatic loss of cumulus cell gap junction is correlated with germinal vesicle breakdown in rat oocytes Developmental Biology 113 517-521

Larsen WJ, Wert SE and Brunner GD (1987) Differential modulation of follicle cell gap junction populations at ovulation Developmental Biology 122 61-71

Lonergan P, Khatir H, Carolan C and Mermillod P (1997) Bovine blastocyst production in vitro after inhibition of oocyte meiotic resumption for $24 \mathrm{~h}$ Journal of Reproduction and Fertility 109 355-365

Motlik J and Fulka J (1976) Breakdown of the germinal vesicle in pig oocytes in vivo and in vitro. Journal of Experimental Zoology 198 155-162

Motlik J, Fulka J and Flechon JE (1986) Changes in intercellular coupling between pig oocytes and cumulus cells during maturation in vivo and in vitro. Journal of Reproduction and Fertility 76 31-37

Petr J, Zetova L, Fulka J, Jr and Jilek F (1989) Quantitative inhibitory influence of porcine cumulus cells upon the maturation of pig and cattle oocyte in vitro. Reproduction Nutrition Development 29 541-550

Richard FJ and Sirard MA (1996a) Effects of follicular cells on oocyte maturation I. Effects of follicular hemisections on bovine oocyte maturation in vitro. Biology of Reproduction 54 16-21

Richard FJ and Sirard MA (1996b) Effects of follicular cells on oocyte maturation II. Theca cell inhibition of bovine oocyte maturation in vitro. Biology of Reproduction $\mathbf{5 4} 22-28$

Salustri A and Siracusa G (1983) Metabolic coupling, cumulus expansion and meiotic resumption in mouse cumuli oophori cultured in vitro in the presence of FSH or dbcAMP, or stimulated in vivo by hCG Journal of Reproduction and Fertility 68 335-341

Sirard MA and Bilodeau S (1990) Granulosa cells inhibit the resumption of meiosis in bovine oocytes in vitro. Biology of Reproduction 43 777-783

Sirard MA, Coenen K and Bilodeau S (1992) Effect of fresh or cultured follicular fractions on meiotic resumption in bovine oocytes Theriogenology 37 39-57

Wert SE and Larsen WJ (1989) Meiotic resumption and gap junction modulation in the cultured rat cumulus-oocyte complex Gamete Research 22 143-162

Received 5 June 2000 .

Accepted 14 September 2000. 